International Journal of Business Management, Entrepreneurship and Innovation, Volume 3, Issue 3, 2021, PP 18-31, ISSN 2707-8027

IBNED

\title{
Assessment of the Influence of Selected Procurement Practices on the Performance of Devolved Government Units in Kenya: A Case of Machakos County Government
}

\author{
Diana Mutete Mutuku', Nickson Lumwagi Agusioma ${ }^{2}$, Julius Wambua ${ }^{3}$ \\ ${ }^{1}$ Student, Master of Science in Supply Chain Management, Multimedia University, Kenya \\ ${ }^{2,3}$ Lecturer, Multimedia University, Kenya
}

ABSTRACT

In the devolved units in Kenya, despite the formulation of strategic plans, majority of the counties remain underdeveloped with the employees remaining reluctant thus citizens' demand for better services remain un met. The devolved systems of governments in Kenya have also been experiencing major challenges in the execution of procurement practices. Counties continue to be criticized for corruption cases, stalled projects, under-development and massive wastage of public resources. All these aspects have been strongly linked to weak procurement management practices which raises concern. The purpose of the study was to determine the influence of contract management practices and procurement policies practices, on performance of Machakos County government. The methodology was descriptive research design that guided the study. The study was carried out in County government offices. The target population and unit of observations was 77 employees in procurement department in Machakos County comprising of senior managers and procurement employees, head of other departments as well budget committee members who were selected using a purposeful sampling approach. Data for the study was collected using questionnaires which were self-administered. The collected data was analyzed using descriptive and inferential analysis using SPSS version 24. Tables and figures were used in presenting the data. The study found out that Contract Monitoring and, Procurement policies had a positive influence on the performance of Machakos County. The study also concluded that for Machakos County to perform, the procurement department must be able to properly implement, monitor and evaluate these practices. The study recommends that the management of the county to improve on the level of compliance with procurement regulations compliance.

Key Words: Procurement Practices, Contract Management Practices, Procurement Policies Practices

DOI 10.35942/jbmed.v3i3.206

\section{Cite this Article:}

Mutuku, D., Agusioma, N., \& Wambua, J. (2021). Assessment of the Influence of Selected Procurement Practices on the Performance of Devolved Government Units in Kenya: A Case of Machakos County Government. International Journal of Business Management, Entrepreneurship and Innovation, 3(3), 18-31. https://doi.org/10.35942/jbmed.v3i3.206

\subsection{Introduction}

Procurements in the public sector often constitute the largest domestic market in developing countries. Based on how effective it is managed, the public procurement system can contribute greatly to the economic development of countries. Because of the sheer volume of spending it represents, well governed public procurement thus plays a major role in fostering public sector efficiency and establishing citizens' trust (Ebekozien, 2019). Well-designed public procurement 
International Journal of Business Management, Entrepreneurship and Innovation, Volume 3, Issue 3, 2021, PP 18-31, ISSN 2707-8027

\section{IBMED}

systems also contribute to achieving pressing policy goals such as environmental protection, innovation, job creation and the development of small and medium enterprises (Mokogi, Mairura, \& Ombui, 2015). Procurement process can be classified into in three diverse ways; sourcing or direct and indirect procurement, and (Minahan \& Degan, 2014). Selection, buying and management of supplies for daily running of company constitutes of the indirect procurement, whereas purchase of products and activities to the manufacture of finished products constitutes the direct procurement. Sourcing applies to both direct and indirect procurement and involves a model divided into four phases: informing, negotiating, and settlement (Kim \& Shunk, 2013). A significant budget is incurred by organizations to purchase good and services at different stages.

According to Public Procurement and Disposal Act (2005), procurement encompasses the whole process of acquiring property and/or services. Strengthening the public procurement in government departments has been a continuous focus since 1990s with revolutionary shift towards the integration of public procurement systems in a significant number of developing and developed countries (Heo, 2013). The immerse focus is attributed to the fact that public procurement is key to government service delivery, yet constraints affect its performance. The procurement is perceived as prone to corruption; occasioning waste and affecting quality of service and life improving opportunities (Chimwani, et al, 2014). Despite various government efforts to improve the procurement system, it is still marred by shoddy works, poor quality goods and services. Globally, public procurement has become an issue of concern and debate, and has been subjected to reforms, restructuring, rules and regulations (Kabega, Kule \& Mbera, 2016). Major setbacks in public procurement have been established to include poor procurement planning and management of the procurement process, needs that are not well identified and estimated, unrealistic budgets and inadequacy of skills of procurement staff responsible for procurement (Mbae, 2014).

Additionally, improper implementation of recommended performance standards results in unnecessarily high operation costs, uncoordinated business activities, inability to achieve domestic policy goals, and failure to attract and retain professionals. Suppliers also tend to complain about the capability of public sector buyers. Therefore, the need to have coherent methods of performance of the procurement function in public entities, particularly in developing countries, has never been as sound as it is now. Delaying will worsen the already deteriorating performance, loss of professionals, and organizations will continue incurring unnecessary costs (Cruz \& Wang, 2018). This is attributed to the fact that many developing countries are challenged by dynamic procurement revolution and this gives them difficulty on the functioning of procurement and performance together with the inside and outside dealings. In Sub Saharan Africa, service provision in the public sector has long been established to be deteriorating with most citizens constantly complaining of unsatisfactory service delivery (Mutangili, 2019).

In Kenya, it is estimated that in Kenya public procurement accounts for over $10 \%$ of the Gross Domestic Product (GDP), making it a large market for suppliers and contractors. With this amount of resource, public procurement tops the list of sectors with high opportunities for corruption (Kariuki, Makokha, \& Namusonge, 2018). Though introduction of the devolved system in Kenya under the new constitution was expected to improve the planning of better public service delivery and maximum utilization of resources, quality service delivery is far from being attained (Ogwoka, Namada, \& Sikalieh, 2017). Particularly, Machakos County continues to experience long period of underdevelopment. Among issues associated with poor performance in the County have been established to be poor management, mismanagement of resources, lack of vision, fraud, misuse of government position and political interferences. Despite strategic plans being formulated, most 
International Journal of Business Management, Entrepreneurship and Innovation, Volume 3, Issue 3, 2021, PP 18-31, ISSN 2707-8027

IBNED

projects remain stalled and underutilized resources with the public officials rarely meeting the set objectives and timelines (Mokogi, Mairura, \& Ombui, 2015). The nature and effect of the procurement practices in the counties is also not well established by the existing literature and this study aimed at shedding more light into this.

\subsection{Statement of the Problem}

In the devolved units in Kenya, despite the formulation of strategic plans, majority of the counties remain underdeveloped with the employees being remaining reluctant thus citizens' demand for better services remain unmet. Additionally, service delivery also lacks uniformity in the standards leading to disparities in citizen delivery causing poor infrastructures and limited access to basic services (Nyongesa, 2014). The devolved systems of governments in Kenya have also been experiencing major challenges in the execution of procurement practices (Ministry of planning and devolution, 2016). After five years of devolution, some counties have been criticized for corruption cases, stalled projects, under-development and massive wastage of public resources. All these aspects have been strongly linked to weak procurement management practices which raises concern.

Notably, while there have been many studies on procurement practices, researchers have not explored the influence of procurement practices on performance of the devolved units in Kenya that have continued to report dismal performance. The studies have also found positive influence of procurement management without detailing what constitutes the ideal procurement practices to achieve the best results. Further, none of the studies seemed to have focused specifically on Machakos County. Poor performance of the counties in Kenya hinders achievement of sustainable economic progress hence investigating this is imperative to realization of Sustainable Development Goals (SDGs). It is against this backdrop that this study was conducted and aimed at answering the research question; what is the influence of selected procurement practices on performance of Machakos County Government?

\subsection{Objectives of the Study}

i. Determine the influence of contract management practices on performance of Machakos County government.

ii. Establish the influence of procurement policies practices on performance of Machakos County government.

\subsection{Literature Review}

\subsection{Theoretical Review}

The study was guided by procurement theory proposed by Johanson and Mattsson, (1987) and provides deep understanding of the many sides of inter organizational relations on insisting the befits of relationships that happen in the organizational parties, development of long term relations that result to trust and cooperative relations as well as mutual relationships in work routines proliferated by exchange processes. By developing this kind of network, the relationships relay the sense of being unique hence leading to supply chain as a personalization to achieve personal customer requirements. The parties involved in this kind of relationship develop trust through social exchange processes (Johanson \& Mattsson, 1987). The rationale to adopt the network theory is its descriptive nature which has been adopted in supply chain management to mark activities and resources in a supply chain. The aim is to build long term relationships and trust within the 
International Journal of Business Management, Entrepreneurship and Innovation, Volume 3, Issue 3, 2021, PP 18-31, ISSN 2707-8027

IBNED

supply chain. An example of network theory application include; seller-vendor relationships. The importance of the theory is providing a framework for understanding the role of procurement management as well as the procurement policies in enhancing both accountability and transparency of the procurement practices at the County government hence improved performance.

\subsection{Empirical Review}

\subsubsection{Contract Management Practices and performance}

Magutu, Chirchir and Mulama (2013) studied the effect of outsourcing logistics services on performance in large manufacturing companies in Kenya. They established that the practice enhanced both organizational and operational performance of the firms in Kenya. Mohammed (2008) also sought to establish the effects of performance contracting on banking industry's operational performance. The study reveals a positive relationship between the two variables. The Public Procurement Oversight Authority (PPOA) also conducted a study on the procurement system in Kenya and found out ineffective contract management practice as one of the reasons for poor procurement performance. It recommends more studies sound contract administration practices in order to boost the performance of the procurement system in Kenya. Nonetheless, the type of performance measured in the study is unclear.

Rotich, (2014) studied the extent to which state corporations in Kenya practice effective contract management. The study findings indicated that state corporations practice effective contract management, which has a positive effect on their operational performance. The implication of the study is that effective contract management improves operational performance of state corporations in Kenya. However, the study recommends constant training, improve contract management practices, use of adequate information systems and enhanced flexibility and risk management. Caritas, Julius and Zenon (2016) researched the impact of procurement practices on performance of Rwandan governmental construction project. Their main intention of the study was to examine the influence of practices of procurement on the performance of public procurement management in Rwanda. They found out that procurement devising strengthens the performance of the construction of Bugesera District office. They indicated that through procurement planning and practices a positive performance in the construction firms is achieved.

Mokogi, Mairura, and Ombui (2015) surveyed the state-owned businesses in Nairobi to demonstrate the impact of procurement practices on performance. Their main objective was to ascertain the significance of procurement practices on the government-owned enterprises performance in Nairobi. They concluded that various enterprises employed procurement practices. The study confirmed that procurement practices are very significant in enhancing the performance of profitable enterprises in Nairobi County. Kiage, (2013) investigated what determined how procurement practices performed taking the cause of Energy Sector. Using a descriptive approach, the study concluded that proper procurement planning was positively correlated to performance. This tends to concur with Cheptora et al., (2018) who studied the determinants of procurement performance among manufacturing firms and established that proper procurement planning through managerial decisions aligning to the procurement goals was positively associated with performance.

\subsubsection{Procurement policies practices and performance}

Government regulatory framework plays significant role in limiting, constraining a right or allocating responsibility or duty to both public and private organizations, says (Okumu, 20013). 
International Journal of Business Management, Entrepreneurship and Innovation, Volume 3, Issue 3, 2021, PP 18-31, ISSN 2707-8027

IBNED

Despite revision of PPDR, 2006 to create the PPDPRAR as echoed by (Okoth, 2013) to lay ground for the implementation of the AGPO policy framework, Ogachi (2013) argues that there still are bottlenecks on its implementation considering that the PPDA of 2005 remains unchanged. This scenario impedes adherence to the government policy as the legal public procurement position lies in the provisions of the procurement law and not the operationalizing regulations or policy directives that seem repugnant to the provisions of the law (RoK, 2005). Amayi, (2013) observed that the public procurement law in Kenya needs to be revised in order to make it relevant and keep it in touch with the requirements of the local supply market, government plans and constitutionalism. These amendments will allow effective participation of the MSEs in public purchasing processes contends (Kiplagat and Leftie, 2013). Although Kenya's ICT sector is headed for sweeping reforms likely to yield an efficient and effective governance system, (Mumo \& Wokabi, 2013) observe that the private sector has persistently experienced hardships when engaging the public procuring entities on the IT front owing to cumbersome procurement laws. This has negatively affected the implementation of the Public Private Partnerships (PPPs) despite the existence of the regulations guiding the initiative.

Despite revision of PPDR, 2006 to create the PPDPRAR (2013) as argued by (Okoth, 2013) to lay ground for the implementation of the AGPO policy framework, there still exist bottlenecks in its implementation considering that the PPADA of 2015 remains intact. The study conceptualized that with rigid public procurement procedures in place, stereotyped contract administration practices, low adoption of advanced technology, weak and outdated policy framework in place, bidding capacity constraints coupled with ineffective procurement operations by the respective oversight agencies and low or even non-participation in procurement, their access and exploitation of public procurement opportunities has been hampered more often and it is likely to persist for unforeseeable future. Koh (2018) provided an alternative perspective to compliance to international and domestic laws. According to Koh, Interaction with international actors are at the core of compliance to international and domestic laws in a number of ways. This includes: the interaction of the institutional stakeholders in the interpretation, enforcement and internalization of the concepts and rules of international laws. According to Koh, domestic countries often seek to comply with international laws as a result of knowledge, familiarity and involvement in the preparation, enactment, and enforcement of the international law.

According to a study by Mair, (2017) Kenya has been experiencing challenges in the implementation of the Public Procurement and Disposal Act of 2015. This has been attributed to various problems and challenges that face procurement. Procurement managers and players especially in the public service often face varied challenges, complex statutes, laws, regulations and policies which complicate the procurement process. Due to complexity of institutions and risks, there is duplication of roles, loss of revenues and resources, inefficiency in the procurement process and low levels of compliance in procurement regulation. This compromises the Interaction with international actors between Kenyan government and internal as well external providers of procurement products. This is especially so in large contracts which have been the source of legal litigation between the Kenyan Government Institutions and Multinational Companies and also a source of conflict between the Kenyan Government and other governments seeking to influence the allocation of government contracts in Kenya.

Kipmayo, (2014) did a study on procurement laws and performance of procurement at KeNHA. The research approach was descriptive collecting data from top managerial employees. Key findings of the study were that procurement laws significantly affected procurement practices. This 
International Journal of Business Management, Entrepreneurship and Innovation, Volume 3, Issue 3, 2021, PP 18-31, ISSN 2707-8027

IBMED

compares with a research by Makabira, and Waiganjo, (2014) who also found a similar positive relationship taking the case of Makueni County. Muange and Chirchir, (2016) investigated the influence of procurement legislation on CDF performance. The study adopted a census approach and revealed that procurement legislation was key factor in defining procurement performance. Similar findings were also established by Oloo, et al., (2017) who studied the health sector in Kenya as well as Mutangili, (2019) who studied KeNHA. Getuno, et al. (2015) recommended that state organs procurement plans for all requirements should be prepared and linked with the approved budget of the organization. Fair and transparent procurement procedures should be used for all procurements with the provisions for reservations and preference clauses for the local MSE firms getting the fairness they deserve. Tender committee should be appointed based on the proven competences and capabilities for procurement know-how and they should be seen to be working diligently.

\subsection{Conceptual Framework}

\section{Independent Variable}

\begin{tabular}{|l|l|}
\hline \multicolumn{1}{|l|}{ Contract Management Practices } \\
Optimizing Vendor Management \\
- Eliminating Manual Process of \\
Creating Purchase \\
- $\begin{array}{l}\text { Streamlining Procurement Processes } \\
\text { - Monitoring and Managing Expenses }\end{array}$
\end{tabular}

\section{Figure 1: Conceptual Framework}

\section{Source: Researcher, (2021)}

\subsection{Research Methods}

Cross sectional research design was adopted in this study to assess the effect of procurement practices on performance. All the employees working in Machakos County Government formed the study population. The target population and unit of observations were therefore 77 employees in procurement department in Machakos County comprising of senior managers and procurement employees, head of other departments as well budget committee members. The heads of other departments targeted were finance, strategy planning, marketing, human resources and operations that are connected to the procurement functions. These respondents are selected as they are directly responsible in overseeing the procurement practices in the county hence most conversant with the study. 
International Journal of Business Management, Entrepreneurship and Innovation, Volume 3, Issue 3, 2021, PP 18-31, ISSN 2707-8027

E-

Slovin's formula (1960) was used to identify the sample size. By applying the formula, a sample size of 65 respondents was studied using at $5 \%$ margin of error.

Slovin's formula is:

$$
n=\frac{N}{1+N\left(e^{2}\right)}
$$

Where $\mathrm{n}=$ number of samples, $\mathrm{N}=$ total population and $\mathrm{e}=$ error margin $/$ margin of error.

$$
65=\frac{77}{1+77\left(0.05^{2}\right)}
$$

The study collected data using structured questionnaires. Both open and close ended questions were used in the questionnaire to facilitate comprehensiveness in the collection of data.

Descriptive statistics and inferential analysis were used to analyse the data. Descriptive statistics including means, frequencies and standard deviations were analysed using SPSS version 24. Inferential analysis on the other hand entailed correlation and regression analysis which enabled determination of the relationship between the research variables. The analysed data was then presented in tables and figures.

\subsection{Data Analysis Results}

\section{1 Descriptive Analysis Results}

\subsubsection{Contract Monitoring and Control}

The study sought to determine contract monitoring and control practices at Machakos County Government. To achieve this, a 5-point Likert Scale was used where 1 is very small extent, 2 is small extent, 3 is moderate extent, 4 is large extent and 5 is to a very large extent. Table 4.5 represents the findings obtained.

\begin{tabular}{|c|c|c|c|c|c|c|c|}
\hline Statement & VSE & SE & ME & LE & VLE & Mean & $\begin{array}{l}\text { Std } \\
\text { Dev }\end{array}$ \\
\hline $\begin{array}{l}\text { Contract management is } \\
\text { committed in ensuring } \\
\text { effective procurement } \\
\text { practices. }\end{array}$ & $5(9 \%)$ & $12(21 \%)$ & $1(2 \%)$ & $11(19 \%$ & $28(49 \%)$ & 3.79 & 1.4606 \\
\hline $\begin{array}{l}\text { There is non-interference } \\
\text { with procurement } \\
\text { processes. }\end{array}$ & $7(12 \%)$ & $8(14 \%)$ & $7(12 \%)$ & $27(47 \%)$ & $8(14 \%)$ & 3.37 & 1.2483 \\
\hline $\begin{array}{l}\text { Ensures the organization } \\
\text { is compliant with } \\
\text { specifications, terms of } \\
\text { reference, statement of } \\
\text { work (quality assurance } \\
\text { and control) }\end{array}$ & $16(28 \%)$ & $18(32 \%)$ & $0(0 \%)$ & $16(28 \%)$ & $7(12 \%)$ & 2.65 & 1.4576 \\
\hline $\begin{array}{ll}\text { Ensures } & \text { organization } \\
\text { compliance } & \text { with terms } \\
\text { and } & \text { conditions, }\end{array}$ & $6(11 \%)$ & $21(37 \%)$ & $11(19 \%)$ & $17(30 \%)$ & $2(4 \%)$ & 2.79 & 1.0977 \\
\hline
\end{tabular}

Table 1 Contract monitoring and control 
International Journal of Business Management, Entrepreneurship and Innovation, Volume 3, Issue 3, 2021, PP 18-31, ISSN 2707-8027

BNE

\begin{tabular}{|c|c|c|c|c|c|c|c|}
\hline Statement & VSE & SE & ME & $\mathbf{L E}$ & VLE & Mean & $\begin{array}{l}\text { Std } \\
\text { Dev }\end{array}$ \\
\hline $\begin{array}{l}\text { paperwork requirements, } \\
\text { and administrative } \\
\text { aspects of the } \\
\text { performance. } \\
\text { Ensures cost control }\end{array}$ & $12(21 \%)$ & $21(37 \%)$ & $14(25 \%)$ & $2(4 \%)$ & $8(14 \%)$ & 2.53 & 1.2692 \\
\hline $\begin{array}{lr}\text { Optimizes } & \text { Vendor } \\
\text { Management } & \text { and } \\
\text { Service-Level Agreement }\end{array}$ & $3(5 \%)$ & $17(30 \%)$ & $7(12 \%)$ & $21(37 \%)$ & $9(16 \%)$ & 3.28 & 1.2064 \\
\hline $\begin{array}{llr}\text { Eliminates } & \text { need } & \text { for } \\
\text { manual process } & \text { of } \\
\text { creating purchase } & \& \\
\text { negotiation orders } & \end{array}$ & $9(16 \%)$ & $14(25 \%)$ & $0(0 \%)$ & $27(47 \%)$ & $7(12 \%)$ & 3.16 & 1.3600 \\
\hline $\begin{array}{l}\text { Streamlines Procurement } \\
\text { Processes }\end{array}$ & $0(0 \%)$ & $16(28 \%)$ & $8(14 \%)$ & $26(46 \%)$ & $7(12 \%)$ & 3.42 & 1.0342 \\
\hline
\end{tabular}

As shown by Table 1, the respondents indicated to a great extent that contract management is committed in ensuring effective procurement practices having a mean of 3.79. On there is noninterference with procurement processes, it optimizes vendor management and service-level agreement, eliminates need for manual process of creating purchase $\&$ negotiation orders and streamlines procurement processes a moderate extent was noted with means of 3.37, 3.28, 3.16 and 3.42 respectively. However, a small extent was indicated on contract monitoring and control ensuring the organization is compliant with specifications, terms of reference, statement of work (quality assurance and control), ensuring organization compliance with terms and conditions, paperwork requirements, and administrative aspects of the performance and ensures cost control with mean of $2.65,2.79$ and 2.53 respectively. This shows that the most adopted control and monitoring control practice was in ensuring effective procurement practices whereas the least was ensuring cost control.

\subsubsection{Procurement Policies Practices}

This section was set out to establish procurement policies practices at Machakos County Government. To achieve this, a 5 point Likert Scale was used where 1 is very small extent, 2 is small extent, 3 is moderate extent, 4 is large extent and 5 is to a very large extent.

Table 2 Procurement Policies Practices

\begin{tabular}{|c|c|c|c|c|c|c|c|}
\hline Statement & VSE & SE & ME & LE & VLE & Mean & $\begin{array}{l}\text { Std } \\
\text { Dev }\end{array}$ \\
\hline $\begin{array}{l}\text { There exists a clear } \\
\text { procurement policy }\end{array}$ & $16(28 \%)$ & $1(2 \%)$ & $9(16 \%)$ & $17(30 \%)$ & $14(25 \%)$ & 3.21 & 1.5554 \\
\hline $\begin{array}{l}\text { There is strict adherence to } \\
\text { public procurement laws }\end{array}$ & $7(12 \%)$ & $4(7 \%)$ & $20(35 \%)$ & $24(42 \%)$ & $2(4 \%)$ & 3.18 & 1.0543 \\
\hline $\begin{array}{l}\text { The county has clear } \\
\text { policies on emergency } \\
\text { procurement processes }\end{array}$ & $6(11 \%)$ & $17(30 \%)$ & $9(16 \%)$ & $18(32 \%)$ & $7(12 \%)$ & 3.05 & 1.2453 \\
\hline
\end{tabular}


International Journal of Business Management, Entrepreneurship and Innovation, Volume 3, Issue 3, 2021, PP 18-31, ISSN 2707-8027

E-

\begin{tabular}{|c|c|c|c|c|c|c|c|}
\hline Statement & VSE & SE & ME & $\mathbf{L E}$ & VLE & Mean & $\begin{array}{l}\text { Std } \\
\text { Dev }\end{array}$ \\
\hline $\begin{array}{l}\text { Procurement policies are } \\
\text { formulated as per the } \\
\text { county needs }\end{array}$ & $1(2 \%)$ & $0(\%)$ & $9(16 \%)$ & $25(44 \%)$ & $22(39 \%)$ & 4.18 & 0.8264 \\
\hline $\begin{array}{l}\text { There is frequent } \\
\text { monitoring and evaluation } \\
\text { of the procurement policies } \\
\text { to access their } \\
\text { appropriateness }\end{array}$ & $1(2 \%)$ & $0(0 \%)$ & $10(18 \%)$ & $19(33 \%)$ & $27(47 \%)$ & 4.25 & 0.8718 \\
\hline
\end{tabular}

The findings obtained revealed that the respondents agreed to a very large extent that procurement policies are formulated as per the county needs and there is frequent monitoring and evaluation of the procurement policies to access their appropriateness with means of 4.18 and 4.25 respectively. However on there exists a clear procurement policy, there is strict adherence to public procurement laws and the county has clear policies on emergency procurement processes moderate extent was indicated with means of 3.21, 3.18 and 3.05 respectively. This findings show that the county is yet to have clear policies on emergency procurement processes. This concurs with Okumu, (2013) who concluded that government regulatory framework plays significant role in limiting, constraining a right or allocating responsibility or duty to both public and private organizations, says Despite revision of PPDR, 2006 to create the PPDPRAR as echoed by (Okoth, 2013) to lay ground for the implementation of the AGPO policy framework, Ogachi (2013) argues that there still are bottlenecks on its implementation considering that the PPDA of 2005 remains unchanged. This scenario impedes adherence to the government policy as the legal public procurement position lies in the provisions of the procurement law and not the operationalizing regulations or policy directives that seem repugnant to the provisions of the law (RoK, 2005).

Amayi, (2013) on the other hand observed that the public procurement law in Kenya needs to be revised in order to make it relevant and keep it in touch with the requirements of the local supply market, government plans and constitutionalism. These amendments will allow effective participation of the MSEs in public purchasing processes contends (Kiplagat and Leftie, 2013). Although Kenya's ICT sector is headed for sweeping reforms likely to yield an efficient and effective governance system, (Mumo \& Wokabi, 2013) observe that the private sector has persistently experienced hardships when engaging the public procuring entities on the IT front owing to cumbersome procurement laws. This has negatively affected the implementation of the Public Private Partnerships (PPPs) despite the existence of the regulations guiding the initiative.

\subsection{Correlation Analysis}

To establish the relationship that existed between the research variables, Karl Pearson's coefficient of correlation was employed by the study. This method entails the measure of the strength of a linear association between two variables and is denoted by r. The findings of the Correlation Analysis are presented in Table 3. 
International Journal of Business Management, Entrepreneurship and Innovation, Volume 3, Issue 3, 2021, PP 18-31, ISSN 2707-8027

E-

\section{Table 3 Correlation Analysis}

\begin{tabular}{|l|l|l|}
\hline \multicolumn{2}{|l|}{} & Performance \\
\hline \multirow{2}{*}{ Contract Monitoring } & Pearson Correlation & $.649^{* *}$ \\
\cline { 2 - 3 } & Sig. (2-tailed) & 0.000 \\
\hline \multirow{2}{*}{ Procurement Policies } & Pearson Correlation & $.856^{* *}$ \\
\cline { 2 - 3 } & Sig. (2-tailed) & 0.000 \\
\hline
\end{tabular}

From the Pearson Coefficient, all the research variables including Contract Monitoring ( $\mathrm{r}=0.649)$ and Procurement Policies ( $\mathrm{r}=0.856$ ), had a positive effect on the performance of Machakos County. Therefore, a unit change in these variables will result in an unit change performance of the county. The effect of all the variables had p-values were less than 0.05 . This means that they can predict the changes in the performance of the county.

\subsection{Regression Analysis}

To determine the relationship that exists between the dependent and independent variables, regression analysis was computed. The results of the regression analysis as shown by Table 4 shows that the procurement practices studied explain $75 \%$ of the variations in performance of the county $\left(\mathrm{R}^{2}=0.750\right)$. This implies that only $25 \%$ of the variation in the performance of the county is explained by factors other than those investigated by the study.

Table 4 Model Summary

\begin{tabular}{llll}
$\mathrm{R}$ & R Square & Adjusted R Square & $\begin{array}{l}\text { Std. Error of the } \\
\text { Estimate }\end{array}$ \\
\hline $.866 \mathrm{a}$ & 0.750 & 1.00 & 0.42 \\
\hline
\end{tabular}

a. Predictors: (Constant), Contract Management, Procurement Policies

The study further undertook ANOVA analysis to establish the validity and effectiveness of the model in explaining the relationship between procurement practices and county performance. The model in Table 4 was found to be valid $\left(\mathrm{F}_{(4,56)}=39.588, P<.001\right)$. This means that the independent variables are a good predictor of variations in performance and were able to predict changes in the performance at any particular time.

Table 5 Model Validity

\begin{tabular}{|c|c|c|c|c|c|}
\hline & $\begin{array}{l}\text { Sum } \\
\text { Squares }\end{array}$ & Df & Mean Square & $\mathrm{F}$ & Sig. \\
\hline Regression & 29.926 & 4 & 6.73 & 39.588 & $.000 \mathrm{a}$ \\
\hline Residual & 8.982 & 52 & 0.17 & & \\
\hline Total & 35.909 & 56 & & & \\
\hline
\end{tabular}

a. Predictors: (Constant), Contract Management, Procurement Policies

b. Dependent Variable: Performance of Machakos County 
International Journal of Business Management, Entrepreneurship and Innovation, Volume 3, Issue 3, 2021, PP 18-31, ISSN 2707-8027

E-

The value of the constant in Table 5 shows that the performance of Machakos County will always exist at a certain minimum $\left(\beta_{0}=0.731, P>0.05\right)$. From the model coefficients, Contract Management $\left(\beta_{1}=0.168\right)$ and Procurement Policies $\left(\beta_{2}=0.974\right)$ were found to affect the performance of the county positively. This implies that an increase in contract management practices and procurement policies will result in improvement of the county performance.

Table 6 Model Coefficients

\begin{tabular}{lllll}
\hline & \multicolumn{2}{l}{ Unstandardized Coefficients } & $\begin{array}{l}\text { Standardized } \\
\text { Coefficients } \\
\end{array}$ & Sig. \\
& B & Std. Error & Beta & \\
\hline (Constant) & 0.731 & 1 & & 0.2958 \\
Contract Management & 0.168 & 0 & 0.19 & 0.0852 \\
Procurement Policies & 0.974 & 0 & 0.85 & 0.0000
\end{tabular}

\section{a. Dependent Variable: Performance of Machakos County}

A similar positive effect was obtained by Brown and Hyer (2010) who anchored their argument for contract monitoring and control on the fact that there are several phenomena which influence project execution and cause actual performance to depart from planned performance. Rotich, (2014) who studied the extent to which state corporations in Kenya practice effective contract management also indicated that state corporations practice effective contract management, which has a positive effect on their operational performance. Further, comparably, from the model coefficient, Procurement Policies $\left(\beta_{2}=0.974\right)$ was found to affect the performance of the county positively. This finding compares to Otieno (2014) who notes the irregular procurement activities in public institutions provide the biggest loophole through which public resources are misappropriated. This compares with research by Makabira, and Waiganjo, (2014) who also found a similar positive relationship taking the case of Makueni County.

\subsection{Conclusions and Recommendations}

\subsection{Conclusion}

According to the study findings obtained under the analysis of the collected data, the researcher makes several conclusions with respect to the research objectives as the data was collected. The study procurement practices studied; contract management and procurement policies affect the performance of Machakos County. The study thus conclude that procurement practices can severely enhance, hamper trade or interfere with a firm's abilities to prosper and perform.

\subsection{Recommendations}

To ensure that procurement policies support effective implementation of procurement practices, the study recommends that the management of the county to improve on the level of compliance with procurement regulations compliance, design and apply better poor procurement policies, support and encourage other staff to execute procurement functions in accordance with the procurement regulations and procurement policies. The procurement heads of department are also recommended to use effective procurement procedures, improve on relationship between management and stakeholders and employ better methods of managing organization resources. 
International Journal of Business Management, Entrepreneurship and Innovation, Volume 3, Issue 3, 2021, PP 18-31, ISSN 2707-8027

E-

\section{References}

Amayi, F. K. \& Ngugi, G. K. (2013). Determinants of Public Procurement Performance in Kenya: Case Ministry of Environment, Water and Natural Resources. International Journal of Social Sciences and Entrepreneurship, 1(5), 647-667

Breevaart, K., Bakker, A., Hetland, J., Demerouti, E., Olsen, O. K., \& Espevik, R. (2014). Daily transactional and transformational leadership and daily employee engagement. Journal of occupational and organizational psychology, 87(1), 138-157. https//doi/10.1108/CCSM11-2014-0158/full/html.

Cheptora, N. C., Osoro, A., \& Musau, E. G. (2018). The effect of managerial style on procurement performance in manufacturing firms in Kenya. International Journal Of Academic Research In Business And Social Sciences, 8(9).

Chimwani, B, Iravo, M., \& Tirimba, O., (2013). Factors influencing procurement performance in the Kenyan public sector: case study of the state law office. International Journal of Innovation and Applied Studies Vol. 9.

Chirchir, E. (2015). Relationship between organizational agility and operational productivity at Kenya Ports Authority. [Unpublished MBA thesis]. University of Nairobi. https//www.erepository.uonbi.ac.ke.

Cruz, J., \& Wang, H. (2018). An examination of the lean leadership practices in the supply chain management. Available at SSRN 3135595.

Dai, Q. \& Kauffman, R. J. (2001). Business Models for Internet-Based E-Procurement Systems and B2B Electronic Markets: An Exploratory Assessment. A paper presented at the ThirtyFourth Annual Hawaii International Conference on Systems Sciences, January 3-6, Maui, HI.

Ebekozien, A. (2019). Unethical practices in procurement performance of Nigerian public building projects: mixed methods approach. Theoretical and Empirical Researches in Urban Management, 14(3), 41-61.

Getuno, P. M., Awino, B. Z., Ngugi, P. K., \& Ondieki, F. (2015). Public Procurement and Disposal Regulations, (2006) Implementation and Performance of Kenyan State Corporations. International Journal of Human Resources and Procurement. 3 (1), 14-37.

Government of Kenya. (2013). Report of the presidential taskforce on parastatal reforms. https://www.apsea.or.ke//76-report-of-presidential-taskforce-on-parastatal-reforms.

Hoe, D., (2013).Financial Supervision: Integrated or Specialized. Journal of International finance, $5(2)$.

Kabega, C., Kule, J. W., \& Mbera, Z. R. (2016). Effect of procurement practices on performance of public projects in Rwanda. International Journal of Economics, Commerce and .Management United Kingdom, IV(5) 377 - 397

Kariuki, J. G., Makokha, E. N., \& Namusonge, G. S. (2018). Influence of Supplier Selection on Procurement Performance in Technical Institutions in Trans-Nzoia County in Kenya.

Kiage, O. (2013). Factors Affecting Procurement Performance: A Case of Ministry of Energy. International Journal of Business and Commerce Vol. 3.

Kipmayo, C. (2014). Role of procurement legislation on procurement performance at Kenya National Highways Authority. Unpublished MBA Project, university of Nairobi.

Kippra, (2016). Public procurement policy in Kenya: The need for a coherent policy framework. Policy brief no. 3/2006

Magutu, P. O. (2013). Critical success factors and challenges in e-procurement adoption among large scale manufacturing firms in Kenya. European Scientific Journal, 9(13), 375-401 
International Journal of Business Management, Entrepreneurship and Innovation, Volume 3, Issue 3, 2021, PP 18-31, ISSN 2707-8027

E-

Makabira, D. K., \& Waiganjo, E. (2014). Role of procurement practices on the performance of corporate organizations in Kenya: A Case Study of Kenya National Police Service. International Journal of Academic Research in Business and Social Sciences, 4(10), 369.

Mbae, N. (2014). Public Procurement Law and Procurement Performance of County Governments in Kenya: Case of Machakos County Government. University Of Nairobi, MBA Project

Minahan, T. \& Degan, G. (2001). Best practices in e-procurement. Boston: Aberdeen group. Mose, J. M., Njihia, J.

Mohammed, A.S. (2008). The impact of performance contracting on operational performance in the banking Industry: a case of multinational banks in Kenya. University of Nairobi

Mokogi, W. N., Mairura, C., \& Ombui, K. (2015). Effects of procurement practices on the performance of commercial state owned enterprises in Nairobi County. International Journal of Scientific and Research Publications, 5(6), 2250-3153.

Muange, E., \& Chirchir, M. (2016). Procurement Legislation and Performance of Constituency Development Fund Committees in Kenya. International Journal of Supply Chain Management, 1(1), 19-33.

Mugenda, O. M., \& Mugenda, A. G. (2008). Quantitative and qualitative approaches.

Mutangili, S. K. (2019). Effects of Procurement Law on Procurement Performance: A Case of Kenya National Highway Authority. Journal of Procurement \& Supply Chain, 3(1), 30-47.

Nair, A., Jayaram, J., \& Das, A. (2015). Strategic purchasing participation, supplier selection, supplier evaluation and purchasing performance. International Journal of Production Research, 53(20), 6263-6278

Nyongesa, N. M. (2014). Strategies Adopted By The County Government Of Mombasa In Raising Revenue. Unpublished MBA Research Project, Nairobi: University Of Nairobi.

OECD, (2014). Performance in OECD countries: A non-radial DEA approach. Acta Montanistica Slovaca, 23(2).

Ogwoka, M. D., Namada, J., \& Sikalieh, D. (2017). Influence of ethical consumer relations on the financial performance of listed firms in Kenya. Journal of Human Resource and Leadership, 2(5), 1-19.

Okoth, J. (2013, October 22). The Reality of Doing Business with Government. Nairobi, The Standard Media Group. P 9.

Okumu, F. (2003). Towards a Strategy Implementation Framework. International Journal of Contemporary Hospitality Management, 1(3), 327-338

Oloo, O., Atambo, W., \& Muturi, W. (2017). Effects of Procurement Practices on the Performance of Public Hospitals in Kenya: A comparative study of Hospitals in Homabay and Kisii Counties. International Journal of Social Science and Information Technology, 3(2), 18991916.

Ong'olo, D \& Odhiambo, S. (2013). SMEs Development in the Devolved Governance System: Policy Options for Institutional and Regulatory Reforms in Kenya, Nairobi. Policy Brief No. 1/2013. CUTS International

Petcavage, S., and Pinkerton, R. (2010).Supply Management. New York.

Public Procurement Oversight Authority (2007). Assessment of the Procurement System in Kenya. Nairobi: PPOA.

Republic of Kenya (2014). Micro and Small Enterprises Authority: Harmonization of Micro and Small Enterprises (MSE) Sector in Kenya, Trans Nzoia County Office, Kitale (Unpublished) 
International Journal of Business Management, Entrepreneurship and Innovation,

Republic of Kenya (2015). Public Finance Management: Manual of the Centre for Parliamentary Studies and Training, New York, Ford Foundation.

Republic of Kenya, (2013). Trans Nzoia County Integrated Development Plan 2013-2017, Kitale, Kitale Printers.

Republic of Kenya, Kenya Gazette Supplement Acts (2015). Public Procurement and Asset Disposal Act, Nairobi, Government Press.

Rotich, J. C. (2014). Contract management practice and operational performance of state corporations in Kenya (Doctoral dissertation, University of Nairobi).

Rwoti, G. (2015). Procurement performance measurement systems - a survey of large manufacturing companies in Nairobi.

Su, J. and Gargeya, V.B. (2016), "Supplier selection in small- and medium-sized firms: The case of the US textile and apparel industry", American Journal of Business, Vol. 31 No. 4, pp. 166-186.

This is an open-access article published and distributed under the terms and conditions of (c) (†) (8)

the Creative Commons Attribution 4.0 International License of United States unless otherwise stated. Access, citation and distribution of this article is allowed with full recognition of the authors and the source. Copyright, content ownership and liability for content herein remain with the authors. 